\title{
Tale of an Innocent
}

\author{
Nicky Singer
}

Published online: 2 September 2006

(C) Springer Science+Business Media, Inc. 2006

\begin{abstract}
The British novelist Nicky Singer talks about becoming a writer, the role of editors and about who decides what can — and what can't—be published either side of the Atlantic. Her three novels explore territory which can make publishers nervous: Feather Boy (initiation rites and domestic violence), Doll (self-harm) and The Innocent's Story (terrorist suicide bombing). The sharply contrasting responses from publishers in the United Kingdom and the United States are described. Through Nicky Singer's sometimes extraordinary experiences with publishers runs the implicit question, perhaps as important now as it has ever been: What constraints should there be on what is explored in books for young readers?
\end{abstract}

Keywords Nicky Singer $\cdot$ Publishing constraints $\cdot$ Feather Boy Doll · The Innocent's Story · Suicide bombing

Nicky Singer began her writing career by inventing stories for her three younger sisters, developing a different set of characters for each child. After an apprenticeship by chocolate (see below) she finally published her first work-lyrics for the cantata Jonah and the Whale-at the age of 16. A series of short stories followed, then four novels for adults and two books of non-fiction. She embarked on her first novel for children following a chance conversation with her then 11 year old son, Roland. Feather Boy-a book about empowerment based on the relationship of a bullied child and a difficult old lady-went on to win the prestigious Blue Peter Book of the Year Award 2002 (a prize inaugurated by the UK's longest-running children's TV programme) and be filmed for the BBC, winning a BAFTA for best drama. Feather Boy's most recent incarnation is as a musical (performed at the National Theatre, London in July 2006) and co-written by Nicky and Peter Tabern, with lyrics by Don Black and music by Debbie Wiseman. Nicky's second novel Doll (short listed for the Booktrust Teenage Award) moved into the darker terrain of motherless children and adolescent self-harm. Her most recent book is The Innocent's Story, her gritty and challenging response to 9/11. Too challenging for her US publisher, who cancelled contracts for the book, it was this book which prompted CLE to invite her to write this article.

Nicky Singer has also worked in the arts and television. In 1989 she co-founded, and for 10 years co-directed, Performing Arts Labs, a charity dedicated to training writers for theatre, screen and opera. She has worked behind and in front of the camera, most notably as the presenter of a six part documentary series for BBC2, Labours of Eve, about women and fertility. She lives in Brighton, on the south coast of England, with her barrister husband, their three children and Tiber the dog.

N. Singer

East Sussex, UK 
When I was six years old I won a bar of chocolate for a story I wrote about a giraffe. 'This is easy money,' I thought. The following year I spotted a national essay writing competition sponsored by Cadbury's. I can't remember what I wrote about that time but I do remember the arrival of a large box (actually it was a tin in those days) of chocolates. It was an annual competition. A tin arrived the next year. And the next. In those heady pre-obesity days, I imagine Cadbury's probably sent a tin to every child who entered, but I didn't think about that. I just scoffed the booty and kept the tins for pencils. When I was 16 my godfather asked me to write some lyrics for a cantata, Jonah and the Whale. That became my first published work and the chocolate turned into money, $£ 19.18$ to be exact—a fortune. By the time I had my first story published in my twenties (runner-up in a competition judged by Kazuo Ishiguro) I had ingested these self-evident truths: you wrote, they published; you wrote, they paid you. Chocolate, money, glory, the currency didn't much matter, what mattered was all this could be unlocked with whatever words you happened to sling on a page.

Imagine then, my astonishment, when, with my first novel (an adult book-To Still The Child), they also gave me an editor. What possible part in the process could she have? In the event, this wonderful, empathetic woman tidied up my grammar, my spelling, my syntax and made one suggestion, that I make cuts in a loft-tidying scene. How could she possibly have known about the loft-tidying scene? I'd re-written it 16 times and, every time, it had got worse. On her advice, I cut it from ten pages to three and it got better. I added another truth to my firmament: an editor was a creature of genius. This effective but low-key editorial involvement and my gratitude for it continued through four adult novels and two non-fiction books.

Then I decided to write for children.

It happened like this: my son Roland, aged 11, was asked to do one of those What-IRead-In-My-Holidays reviews. On the back of his review, five other children in his class went out and bought the book. I was astonished. 'You're doing better than my agent and publisher put together,' I remarked. 'Why don't you become my agent?'

'I will,' replied Roland in one of those off-the-cuff-change-your-life remarks, 'if you write something for my age-group.'

I live by the sea and often walk there to think. So off I went thinking, but it was April and very cold and my brain seemed frozen. I turned inland, taking a road I didn't know towards home. There stood a huge derelict house. I decided to go in which, in a town with a heavy drugs problem was not a wise idea. Everything in the house was sledge hammered; the tile floors, the basins, the baths. Paper was ripped off the walls, there was the inexplicable sound of water, drip, drip, dripping. I went upstairs with my back to the wall, so no-one could come at me from behind. My heart was jumping in my chest but I still went on, right to the top of the house. On the top floor there was an empty bedroom, a bedroom with a bloodstained mattress, a sledge hammered bathroom and a shut door. I went through the shut door. I thought all of Brighton would be able to hear my heart-but inside that room was absolutely nothing. I stood there more frightened than I've ever been in my life thinking, 'There can't be nothing here. I can't have gone through all this for nothing!' Which is when the 'what ifs' started. What if there is something in this room, only I can't see it right now? What if something happened in this room a long time ago, which still has resonance down the years? All around the room, in faded wallpaper, were a million mother ducks and their three little ducklings. It had been a child's room. What had happened to the child? Feather Boy was born in that moment. The real live house was called Select House, in my book I called it Chance House. 
I was buzzing with ideas but I was also aware that I knew nothing about writing for children. As the enterprise had been Roland's idea I reckoned he had an obligation to help me. I work in an extremely linear way, writing chapter one until it's as good as I can make it and only then progressing to chapter two. When I get to the last chapter, that's the end of the book, I don't then go back and re-write. So I was able to read the manuscript that became Feather Boy sequentially to Roland. He gave me his unexpurgated criticism which ranged from falling asleep (chapter not quite engaging enough); dissing my vocabulary ('No boy my age would say that, Mum!'); enquiring about when we would next return to graveyards/old houses (crucial information on what expectations I was setting up). The only time I didn't act on Roland's advice was when he described a particularly beautifully written passage as 'boring'. The child has the attention span of a gnat, I reasoned, what does he know?

I put my prep in an envelope and sent it off. Five publishers bid for the book. One of them was Barry Cunningham of Chicken House, the man who had edited the first Harry Potter book. My agent and I did the rounds and I asked each publisher in turn whether he or she would edit anything. 'Yes,' said Barry, flipping through the manuscript and putting his finger on the Very Beautiful Passage. Brilliant man, I thought, I want him. (And, yes, I simultaneously revised my opinion of my son.) But that relationship wasn't to be and the book was finally taken by Collins. I purged the beautiful passage myself and re-submitted the work. It went through the most minimal of copy edits and headed off for the outside world. In retrospect I realise that it had such light touch editing in the UK because of the superb job done by my son-one of the finest editors I've had the privilege of working with.

Enter the Americans.

They paid a lot of money for Feather Boy. A lot of money. Then they sent a 16 page e-mail of editorial suggestions. I read the suggestions with mounting disbelief, the book that they felt needed so much work was poised to be published-almost untouched-in the UK. Besides, I reckoned that if I acted on all their suggestions not only would they not have the book they'd paid for, they probably wouldn't have a book at all. Two particularly galling revisions were proposed, the first concerning the Grape Incident. Disclaimer: the following paragraph may contain material offensive to some US adults.

There I was lying in the bath (no, not that, which is the best thing about being a writer, you can do it pretty much anywhere) when this 40 year old man rang in to a radio programme clearly desperate to say something. The interviewer talked all over him for a couple of minutes and then finally the man blurted it out: when he'd been a child he'd been forced to take part in an initiation ceremony, a race with two other boys. The three of them had been made to crawl on their hands and knees, naked, with a grape wedged between the cheeks of their buttocks. The child who came last in the race had to eat the grapes. I leapt out of the bath and grabbed a pencil and began scribbling. On the radio the man was crying. (That's the bad thing about being a writer-the ruthlessness.) I made this story a seminal part of the bullying of my fictional child. The incident hangs over Robert; he hates to go down supermarket aisles in case he sees any fat, green grapes...

My American editor-let's call her Jo-said this incident had to go. She informed me that, in America, it's called hazing and they have laws against it. It took me a whole month to pluck up courage to write that in this country we have laws against murder. I contemplated adding 'but it doesn't stop it happening', just in case she didn't get the point. 
Jo was aggrieved at my combative stance. If I wouldn't cut the scene, perhaps I could 'tone it down'? I explained that, as far as I was concerned, an incident like this was like a rape, either it happened or it didn't, and if it did, there were consequences, witness the 40 year old radio man. The point of my book, I suggested, was that my main character, Robert, was going to rise above the psychological damage; if there was no damage he'd have trouble rising above it.

Jo temporarily let that one rest and got her teeth stuck into the Marital Violence Issue. She didn't like that either. This is what happens: Robert's parents are having a bad time and the father hits the mother. Once. It's made quite clear in the book that this is an isolated incident of loss of control which is a direct parallel for the moment, later in the book, where Robert himself finally loses control and slugs the Grape Incident bully. It is not, in my view, gratuitous. Neither is it, any longer, in the American edition. Jo said, if I left it in, I would have the book I wanted, but no-one would buy it; the librarians who (I was told) control the market in the US in a way that they don't in the UK, wouldn't buy it, the librarians' first obligation being to protect young minds. I had to choose which of my babies to sacrifice (editing, as I have discovered is the art of compromise) - the Grape Incident or the Marital Violence. I chose to keep the Grape Incident and ditch the violence. Thus the brutal British edition reads:

'How come grown-ups are always so smart about your life, but not so smart about their own? Slap, slap, slap. That was dad hitting her on the landing. Well, hitting her on the face actually, out on the landing. Or maybe on the shoulders. I didn't really want to look. I could hear plenty enough. Anyhow, I didn't notice her trying to make him into a friend the next morning.'

And the American:

'How come grown-ups are always so smart about your life, but not so smart about their own? Yell, scream, yell, smash. That was Dad out on the landing. Dad and Mum and the Imari dish. Mum's favourite dish. The one she kept rose petals in. Smashed against the wall. Well, I don't know if it was the wall, because I wasn't exactly out on the landing taking a look. I was in my room with the door firmly closed. Tell the truth, I didn't really want to look. I could hear plenty enough. Anyhow, I didn't notice her trying to make him into a friend the next morning.'

When I first ran this version past Jo, she said: 'He's throwing the dish at her, isn't he?'

I said: 'No, you just know he used to hit her so you imagine he's throwing the dish at her. But he isn't.'

But he is actually.

Anyway, Americans might like to know that theirs are the most protected children in the world. The hitting is extant in Germany, Spain, the Netherlands, Israel, Japan, Korea, in fact in all of the 24 other countries where Feather Boy is published. I should have learnt something from that. But I didn't.

While Feather Boy is a 9-12 year old read, my next book Doll is for teenagers. I was on a tour in the north of England with Feather Boy (which, notwithstanding its violence and its dirt, had won a number of prizes) when I told a Stockton librarian that my new book included scenes of self-harm.

'Oh,' she said, 'one for the office then.'

I asked her what she meant. She meant, apparently, that books with 'difficult' themes couldn't be left on library shelves for teens to blunder into accidentally, they had to be kept safe in the office. So a girl regularly cutting her arms and browsing for a book which had resonance for her situation would have to know the book was in the office (how exactly?) and then come and ask for it? 
'Yes,' said the librarian. 'I know it's mad, but it's not us, it's the parents. If we have that sort of book on the shelves, they complain.'

$\mathrm{Ah}$-not the librarians then, the parents. A Kafkaesque gate-keeping world was beginning to emerge. Re-Enter the Americans. They were twittery about Doll. Their concern - they said-was that the book was written for such a different age group from Feather Boy, it would be difficult to rearrange my profile from children's writer to Young Adult writer. Perhaps it would be better to delay publication of Doll until after my third book. That book was going to be for 9-12 again, wasn't it?

I said I thought it probably was. But I'd reckoned without $9 / 11$. It was the summer after the attacks, I had begun to research a book about heaven, but the images of the Twin Towers wouldn't leave my mind. I still remembered the precise thoughts that ran through my head when the second tower collapsed: Who could hate us this much and me not know? And What can I do or give to these people so they never want to do this again? There's hubris in the first thought and danger in the second, but that's the truth of what I felt in the frozen in time moment. A year on we thought we knew who had 'done it' but as for the trigger behind the anger, the thing that would drive one human being to think it was appropriate to blow up another, that remained a mystery to me. And I wanted to know. The book about heaven began to merge with one about suicide bombers.

Did I stop at this point to ask whether it was appropriate to write about suicide bombing for children? The truthful answer to this is 'no'. But that's probably because I come from a place where children are neither excluded from life nor excused its traumas. My own growing-up began when I was a scant 14 and my father died so suddenly my mother was put under house arrest on suspicion of having poisoned him. That was the moment my mother began treating me as an adult. When it turned out she hadn't poisoned him (the autopsy revealed a one million to one medical cause) the adult bond stayed. I've replicated this in my relationships with my own children and talking openly about difficult subjects is one of the delights of my family life. But the wider world doesn't always view things this way. Re-enter the Land of the Free.

I sent my US publisher the manuscript of The Innocent's Story. The novel opens (bear in mind I finished this book 18 months before London 7/7) with a suicide bomb going off in a London train station. The narrator of the story is a 13 year old child killed in the explosion. She becomes a 'para-spirit', only able to survive if she holes up inside a living human's head. As luck and fiction would have it, she ends up in the head of a bomber, because that's what the book is, an attempt to get inside the head of a bomber. So far so scary. The was a large silence from the other side of the Atlantic.

Large silences from publishers (I'm getting smarter at understanding publishers now) are generally bad. This one certainly was. They didn't think they could publish The Innocent's Story, nor in fact could they publish Doll. The stated reason behind the rejection of Innocent's Story was that it was 'too political'. I was stunned. I thought if you handed in a picture book when you'd promised a 500 page novel, that might be cause for rejection. Or maybe if you just handed in a truly terrible book-but too political, what could that mean?

Meanwhile back in London my British editor had written to say the book was 'interesting, intelligent, provocative and important'. Politics didn't seem to be on the agenda, we got to work on an edit. But among the higher echelons, the US reaction had de-stabilised things. With an innocence all of my own, I didn't really see the problem.

Turns out there wasn't a problem singular, there were problems plural. I'd crossed too many lines. The first of these was the 'wanting to open a discussion with children' one. Could I justify myself? I thought I could, because there's a kind of schizophrenia 
here: as parents, or even simply as decent-minded adults, we like to think we can protect our children from some of the worst horrors of the modern world, but actually they are exposed all the time. When our media culture beams the horror into our living rooms it also, willy nilly, beams it into our children's lives. There will be no child on earth with access to a television who did not see pictures of the twin towers falling; no child in London unaware of the July bombing. What do they do with this knowledge, who speaks to them about it, how does it affect them?

The least our children deserve, I argued, is a context for the events they witness around them. If we say nothing about the bombs to our young people it gives terror a kind of legitimacy, makes it ordinary, not something worthy enough to be remarked upon. The usefulness of fiction in this process is that it can offer a 'safe space' for that discussion. Terrible events can be realistic but not real. Love and morality can sit alongside difficulty and grief. And the experience of a book and the issues it raises can also be shared at school, or among a peer group. We understand that, said the publishers, other people may not. Re-run the librarians/parents argument.

The next difficult line was the 'sympathising with terrorists' one. In England at that time, one of our senior Liberal Democrat politicians-Dr. Jenny Tonge-had just been sacked after attending a meeting of Palestinians and making remarks which allegedly suggested she understood where their suicide bombers were coming from. But, for me, there is a world of difference between sympathy, where you agree a person's premise, and empathy where you attempt, for a moment, to stand in that person's shoes and wonder whether, if you'd walked their path, you'd have ended up where they ended up. And the more we understand about what motivates people to suicide bomb the more likely we are, in my view, to be able to do something about it.

Next frightening line: religion. All sides of the religious divide currently appear to wish to legislate-sometimes violently-about what can and can't be said artistically about their faith; recently in England we've witnessed Sikh outrage at the Birmingham Rep production of Behzti, and Christian Voice's attacks on Jerry Springer the Opera. My research on suicide bombers turned up two basic types, the politically motivated who use religion as a fig-leaf and the genuinely religiously motivated. I didn't see how I could write a book about the inside of a suicide bomber's head without inquiring into the role of religion. I didn't want my readers bringing any baggage to the religion I chose but it seemed disingenuous to settle upon a radical sect of Icelandic Quakers. I decided to make up my own religion. I needed something close enough to the truth to feel real, but far enough away from reality not to demonise or offend. Enter the T'lanni religion with its radical Haliki sect. My UK editors said, to be safe, perhaps we should get an Islamic scholar to cast an eye over this dangerous ground?

The Islamic scholar declared that the T'lanni religion was a thinly disguised version of Islam. But-despite a millennia of religious conflict which would have you believe otherwise-all religions are to some extent thinly disguised versions of each other. Take for example Christianity, Judaism, Islam, they all have their single deity (whether it be God or Allah) their Holy book (whether it be the Bible, the Torah, the Koran), their principal witness (Christ or Abraham or Muhammad). I used this basic structure: My god is J'lal, my book the Holy Desert Scrolls, my witness the angel Ingali. Now here's a thing the grown-ups don't get: children do not think like them. When I gave the manuscript to my eat-books-for-breakfast 12 year old friend Hannah, she said: 'It's brilliant-except, well, I've never heard of the T'lanni religion and we do Comparative Religion at school.' Game on. 
The other advantage of an invented religion is that you can draw parallels. My religion has an equivalent of 'jihad' but only to make it clear that, far from being exclusively associated with 'holy war' (which you would think by reading the western press) the predominant meaning of 'jihad' in the Koran is the literal Arabic one 'to strive hard' and it's used, for instance, to mean the attempt to get closer to god by overcoming bad desires. I didn't know that before I began my research. I wonder if you did.

Still things were getting serious. There's a dangerously obsessed Christian character in the book, were we going to have to wheel on a Christian scholar? The main character spends an evening in the brain of a dog, did we need a view from the Royal Society for the Protection of Animals? I jest, of course. But not much. I got told off for jokes. If the book's about such a serious subject then it shouldn't be so humorous, my editor intoned. I mentioned, only a tad defensively, that the gravediggers' scene in Hamlet isn't there because Ophelia's death doesn't matter but because human beings can't bear very much reality. Adult ones anyway. My friend Hannah likes a good laugh.

Finally, and very seriously, what I aimed for in the book was complexity and that I realise (again rather late in the day) is another line I've crossed. Our increasingly complex world is increasingly simply — and inadequately-described. Take, for example, the phrase 'The War on Terror'. That has no more meaning than a war on 'shooting' would because terror is not the thing, it's a symptom of the thing. The politically useful-but deluding - thing about the term War on Terror is that it lumps everyone together: religious fanatic, Palestinian, Chechen. All of them conveniently characterised as The Other, The Enemy, as in Them and Us, Goodies and Baddies. Disney stuff, kids' stuff. But these are not the same peoples with the same grievances. If we are going to address their problems-which have become our problems-we need to ask deeper questions. The going into the minds of the terrorists type ones. Oh, oh, here we go again.

Six months passed. I handed in my revised manuscript. There was a silence. You've probably heard this story before. Collins UK didn't think they could publish the book, not because of the politics, but because the novel 'didn't work'.

I wasn't stunned this time, just saddened and very let down. I realised for the first time that the book represents me in a way nothing I've ever written before does, it's about the no-holds-barred part of me, the part that, when I see a sign saying 'keep off the grass' wants to go and have a little tread. For the first time the rejection felt personal.

My agent-bless her forever-remained bullish. 'It's a fabulous book, it will find a home.' And it has-with Oxford University Press. Oxford is not owned by an American conglomerate. OUP is owned by the University of Oxford with its 527 year tradition of research, education, scholarship and free speech. They declared the book to be the 'best thing they had read for ages'. They understood the project, they were not afraid.

So, almost 2 years after I finished the book, it finally hit the stores. The July 7 th London attacks made the publication date look opportunistic, but I knew the truth of the timing and felt I could hold my head high. I'm proud of this book and everyone who has had the courage to go with it. Yet I still waited for the sky to fall in, or for it to at least rain fatwas. That didn't happen. The world is perhaps saner than we knew.

The worst that happened was a vicious piece in The Times by a reviewer who compared The Innocent's Story unfavourably with an adult novel without once mentioning that The Innocent's Story is written for children. But gradually this novel which is too political and doesn't work, began to garner praise: 'tender, thoughtful and idealistic, this is a tough but immensely worthwhile read', (The Independent); 'This tense, 
gripping novel could hardly be more topical, raising questions of faith, loyalty and responsibility'. (The Times Educational Supplement). In the same week the novel was long listed for the Carnegie Medal and short listed for the Stockport Book Award. And what's way more important, the kids (reading for book clubs and prizes) awarded the book ' $11 / 10$ ' and declared it 'awesome'.

In the foreign markets my adored German publishers turned it down. I didn't enquire why, part of me didn't want to know. The Italians, by contrast, loved the book and made an immediate offer. In the States time passed. I knew that if the book really was 'too political' for America, then the silence would lengthen. But it hasn't, another forward thinking press, Holiday House, has made an offer. The book will finally appear in the US in Autumn 2007.

Somebody send me a box of chocolates.

\section{References}

Nicky Singer's titles for young readers:

Feather Boy (2002). London: HarperCollins.

Doll (2003). London: HarperCollins; New York: Random House.

The Innocent's Story (2005). Oxford: Oxford University Press. 